\title{
The Late Weichselian glacial maximum in western Svalbard
}

\author{
JAN MANGERUD, MAGNE BOLSTAD, ANNE ELGERSMA, DAG HELLIKSEN, JON Y. LANDVIK, ANNE \\ KATRINE LYCKE, IDA LØNNE, OTTO SALVIGSEN, TOM SANDAHL AND HANS PETTER SEJRUP
}

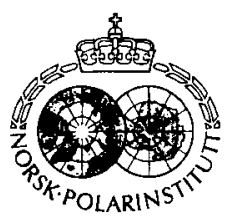

Mangerud, J., Bolstad, M., Elgersma, A., Helliksen, D., Landvik, J. Y., Lycke, A. K., Lønne, I., Salvigsen, O., Sandahl, T. \& Sejrup, H. P. 1987: The Late Weichselian glacial maximum in western Svalbard. Polar Research 5 n.s., 275-278.

Jan Mangerud, Magne Bolstad, Anne Elgersma, Dag Helliksen, Jon Y. Landvik, Anne Katrine Lycke, Ida Lonne, Tom Sandahl and Hans Petter Sejrup, Department of Geology, Sect. B, University of Bergen, Allégaten 41, N-5007 Bergen, Norway; Otto Salvigsen, Norsk Polarinstitutt, P.O. Box 158, N-1330 Oslo lufthavn, Norway.

The glacial history of Svalbard and the Barents Sea during the Late Weichselian has been much debated during the last few years; reviews are presented by Andersen (1981), Boulton et al. (1982), Elverhøi \& Solheim (1983) and Vorren \& Kristoffersen (1986). In our opinion (Mangerud et al. 1984) it is now demonstrated that a relatively large ice-sheet complex existed over most of Svalbard and large parts (if not all) of the Barents Sea. One of the main arguments for a large ice sheet is the pattern of uplift, including the 9,800 B.P. date on the $100 \mathrm{~m}$ shoreline in Kong Karls Land (Salvigsen 1981). Important unresolved problems include how large that ice sheet was, the location of the different ice domes and ice fronts, the age and duration of the glacial maximum, and the deglaciation history. We will here report on these problems bringing some results from the Van Mijenfjorden and Isfjorden area (Fig. 1); a more comprehensive paper is in preparation.

\section{Evidence}

Radiocarbon dates on shells, of which most were collected in stratigraphical positions that suggest they lived shortly after the deglaciation, are plotted on Fig. 1. The pattern indicates that the ice front halted at Akseløya at the mouth of Van Mijenfjorden for some centuries around 11,000 years B.P. This conclusion is substantiated by the sea level history, because the 11,000 year shore line which was mapped along the coast from Bellsund to Isfjorden (Landvik et al. 1987) does not continue into Van Mijenfjorden, where only lower and thus younger shore lines occur.

In a section in Skilvika (Fig. 1) the fabric in the only existing Late Weichselian till shows deposition from a glacier flowing NNW, out Recherchefjorden. Radiocarbon dates from a glaciomarine clay just above the till gave $12,830 \pm 210$ (T-6000) and $12,570 \pm 160$ (Ua-280) years B.P. (Fig. 1). Below this till a horizon with frost-weathered stones indicates subaerial conditions.

Along the coast from Bellsund to Isfjorden we have mapped glacial striae, perched boulders, and other evidence for ice lobes flowing out of the valleys (Fig. 1). Between the valleys conclusive observations for or against glaciation are lacking (Landvik et al. 1987).
Linnedalen is the westernmost valley on the south shore of Isfjorden (Fig. 1). All mapped glacial striae and till fabrics indicate an ice movement towards the north, i.e. down valley. We assume that they exclude the possibility of an ice stream coming out of Isfjorden at the time of their formation. Stratigraphic sequences along the river Linnéelva cover much of the Weichselian; all pebble counts, till fabric analyses and sedimentary structures measured in these sediments record a transport from local sources. We conclude that the last ice advance out Isfjorden (Ohta 1982) probably predates this sequence, and that the early Weichselian is a minimum age for such a glaciation. The deglaciation of Linnédalen can be dated just prior to 11,600 years B.P. based on accelerator radiocarbon dates on molluscs from the basal glaciomarine clay in cores raised from the lake Linnévatnet (Svendsen et al. this volume).

\section{The extent and configuration of the glaciers during the Late Weichselian ice maximum}

A complex calving bay in Bellsund can be reconstructed (Fig. 1). A fjord glacier in Van Mijenfjorden grounded on Akseløya, while ice streams out Van Keulenfjorden and Recherchefjorden calved along the southern border of Bellsund. This scenario represents a definite minimum extension for the Late Weichselian ice and a possible, and indeed reasonable, model for the ice maximum. Based on the deglaciation dates from Skilvika, the reconstruction can be dated just prior to 12,700 years B.P. The van Mijenfjord glacier remained at Akseløya until after 11,000 B.P. Currently, we have no observations that suggest a substantially larger Late Weichselian glaciation around Bellsund.

The Van Mijenfjord glacier may have been an outlet glacicr from the Barents Sea Ice Sheet. However, the date from Agardhbukta (Fig. 1) suggests that the eastern coast of Spitsbergen was ice free before Kjellstrømdalen on the western side, so at least during the final stages of the deglaciation the valley glaciers to the west originated from local ice domes on Spitsbergen. During the glacial maximum, ice was no doubt contiguous from Van Mijenfjorden to the Barents Sea, even if the ice was dynamically separated into several domes.

Glaciers coming out of Van Keulenfjorden and 


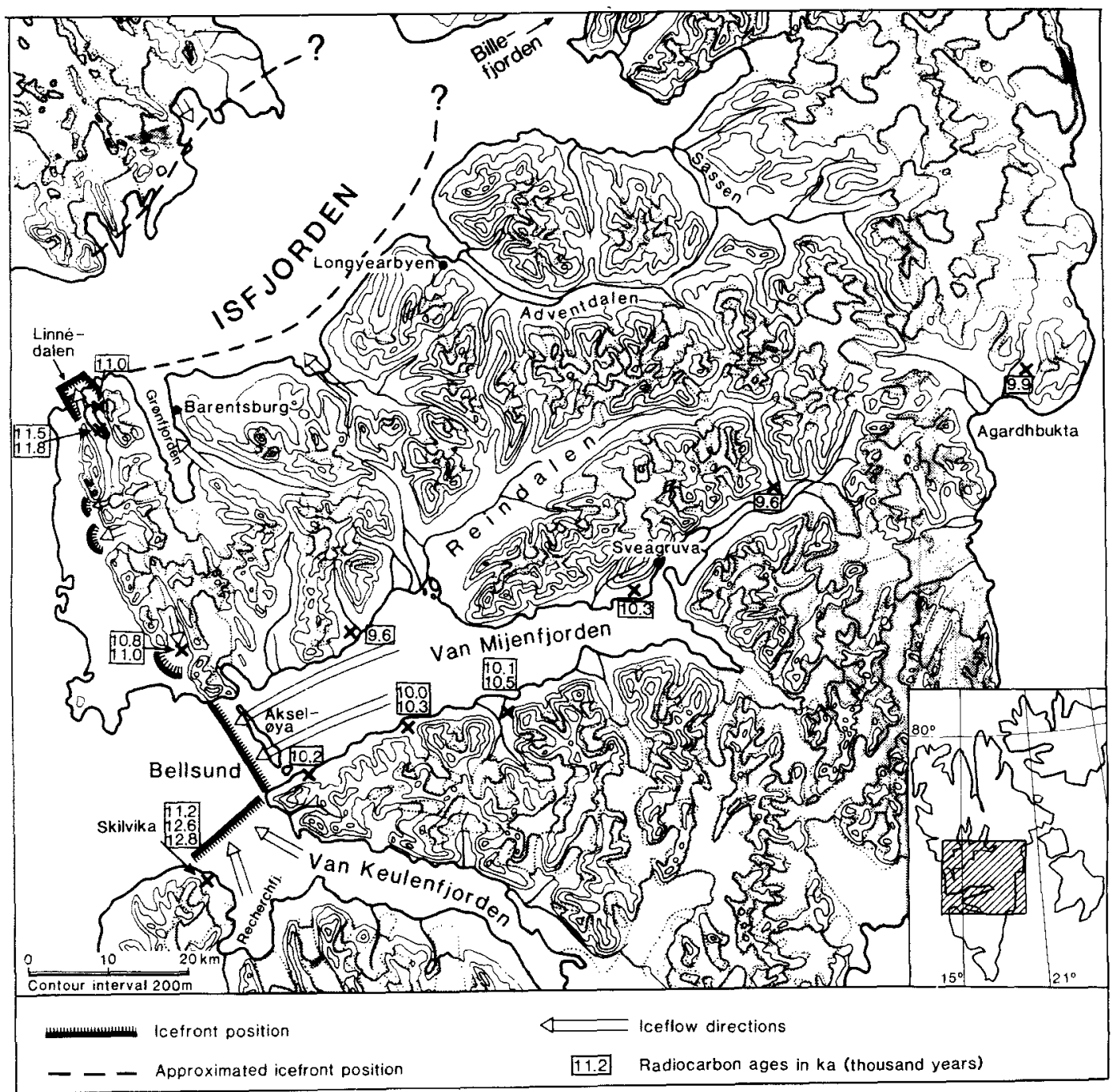

Fig. 1. Radiocarbon dates indicating minimum ages of the deglaciation are given in ka (thousands of years). Some reconstructed ice margin positions are shown. These represent minimum extensions of Late Weichselian glaciers.

Recherchefjorden suggest an ice dome to the south of these fjords. Also between Bellsund and Isfjorden there must have been a separate ice dome with outlet glaciers radiating along the valleys to the north, west, and south. This reconstruction is a secure minimum model for the Late Weichselian ice maximum, and also a possible reconstruction of that maximum.

In Linnédalen we feel more confident that the reconstructed ice margin (Fig. 1) also represents the Late Weichsolian maximum, even though that assumption is not unambiguously proved. However, the interpretation that the outer part of Isfjorden remained ice free during the Late Weichselian is supported by the reconstruction of an ice free west coast to the north of Isfjorden (Boulton et al. 1982; Forman \& Miller 1984) and by our mapping along the northern shore of Isfjorden, where nearly all observations of glacial features indicate ice movement towards the fjord only. For the outer part of Isfjorden we therefore reconstruct the Late Weichselian ice maximum as tide water glaciers along both shores, flowing out from local ice caps or domes situated north and south of Isfjorden. We assume that the last glacier which advanced out of Isfjorden, and deposited the moraines described by Ohta (1982) to the west of the fjord mouth, is of early Weichselian or pre-Eemian age.

Further east in Isfjorden data are not available for a secure reconstruction. Our reconstruction in Van Mijenfjorden postulates major glaciers coming down Sassendalen and Adventdalen towards Isfjorden, and a reasonable assumption is that the main ice front crossed Isfjorden somewhere north of Longyearbyen. Boulton (1979) mapped an end moraine across the mouth of Billefjorden. Other marine geological observations from Isfjorden (Elverhøi et al. 1983) are not conclusive regard- 
ing the location of an ice front. Boulton (1979) postulated a young ice advance over the Kapp Ekholm site in Billefjorden, based on a young radiocarbon date from a till. However, it was demonstrated (Mangerud \& Salvigsen 1984) that shells in living position above that till yielded infinite ages. This had in fact been described before by Troitsky et al. (1979) who assumed that Late Weichselian ice had not overrun the site because no till covers the sediments with the 'old' radiocarbon and TLdates. However, they generally reconstructed much smaller Late Weichselian glaciers on Spitsbergen than we do in this paper. Our plan is to reinvestigate the site at Kapp Ekholm and the surrounding area before drawing any final conclusion.

We propose a model of the Late Weichselian glacial maximum (Fig. 1) with two styles of glaciation: local ice domes on western Spitsbergen and a major Barents Sea ice sheet, and with Van Mijenfjorden glaciated whereas most of Isfjorden was ice free (Mangerud et al. 1984).

\section{Age and duration of the Late Weichselian ice maximum}

The timing of the high-latitude glacial events in the SvalbardBarents Sea, relative to the mid-latitude glaciation of Scandinavia, or to Antarctica, is crucial for understanding the dynamic response of the earth's systems to the orbital forcing of climatic change (Denton et al. 1986). Two views are held for the age of the Late Weichselian ice maximum in Svalbard: around 18,000 years B.P. (e.g. Denton \& Hughes 1983) and around 11,000 years B.P. (e.g. Boulton et al. 1982). Neither of the two assumed ages are contradicted by field observations. even though our observations rather point to there being an age between the two.

As pointed out above, there were two glacial systems in this part of the Arctic: a Barents Sea ice sheet complex that was mainly marine-based, and local, mainly land-based ice domes on Spitsbergen. Possibly the two systems were not in phase, neither during their growth and maximum nor during their decay. The relative timing will be important to understand how the two systems responded to sea level and climatic changes. We assume that the late glacial uplift of western Spitsbergen mainly was a glacio-isostatic response to decay of the Barents Sea ice sheet. The deglaciation of the local ice domes on Spitsbergen occurred during that period of emergence, 12,000 to 9,000 years B.P., and was thus roughly in phase with the deglaciation of the Barents Sea ice sheet. With the accuracy of available data, we cannot resolve whether there in detail were leads or lags between the two glacial systems during the deglaciation.

From Svalbard many finite radiocarbon dates in the interval 15,000 to 40,000 years B.P. are reported, most, if not all, from samples consisting of several mollusc individuals or fragments. Thus, the ages might in many cases represent means of mixed age populations. We obtained a date of $16,760 \pm 180$ (T-6617) for shell fragments from a terrace $65 \mathrm{~m}$ a.s.l. in Linnédalen, well inside the Late Weichselian boundary. Subsequently obtained amino acid $\mathrm{D} / \mathrm{L}$ ratios from 0.017 to 0.028 on different fragments suggest that it was a mixed age population, an assumption confirmed by an accelerator date of $11,000 \pm 190$ (Ua-279) on the fragment with the lowest $\mathrm{D} / \mathrm{L}$ ratio.

The youngest radiocarbon ages we have obtained for molluscs in living position inside the Late Weichselian ice limit are $36,100 \pm 830(T-5211)$ and $35,900 \pm 500(T-6618)$. As with all old shells, they might be contaminated, so the age is a minimum age. However, a 'low age' is supported by low D/L values, described below. The shells are from a morphologically distinct terrace $87 \mathrm{~m}$ a.s.l. in Linnédalen, where we recently found a thin cover of an unambiguous basal till. The till cover demonstrates a glacial advance after the deposition of the shells and the terrace. Therefore the mentioned lack of radiocarbon dates younger than 36,000 years could indicate that the area was ice covered from 36,000 to around 12,000 years B.P. Hardly any reliable radiocarbon date from Svalbard would contradict that assumption, whereas it is in strong conflict with the amino acid data given below.

Amino acid analyses of the shells from the $87 \mathrm{~m}$ terrace yielded a mean total $\mathrm{D} / \mathrm{L}$ value of $0.020 \pm 0.004$ (BAL-388, $-673,-674,-677)$ for 8 individuals. Such low values have not earlier been identified for shells from Svalbard with a radio. carbon age of more than 12,000 years (e.g. Miller 1982; Forman \& Miller 1984). The low $\mathrm{D} / \mathrm{L}$ values provide strong constraints on possible diagenic temperature histories, and thus post-depositional sea level and glacial histories. Mean annual temperature for the area today is close to $-5^{\circ} \mathrm{C}$; during ice-free periods in the Weichselian it was probably much colder, whereas below glaciers and sea level it would be close to zero. For 10-12,000 year old shells which have been above sea level for most of the time, we have obtained a $D / L$ value of $0.015 \pm 0.003(n=35)$. The till-covered $87 \mathrm{~m}$ terrace was deglaciated around 11,500 years B.P., and with a preceding ice cover of 5,000 years only, the shells would have had a $\mathrm{D} / \mathrm{L}$ value of 0.020 . For the rest of the period back to 36,000 (or more) years B.P. one must postulate such low temperatures $\left(-20^{\circ} \mathrm{C}\right.$ or lower) that essentially no racemization took place. With the limitation that the $D / L$ ratios are obtained from one locality only, they suggest that Linnédalen was ice free for most of the period after 36,000 years B.P., and that this Late Weichselian ice dome was very short lived. As mentioned above, this reconstruction is apparently in conflict with the missing radiocarbon dates for the period after 36,000 years B.P. However, this might be explained by assuming a low relative sea level for most of that time, so that no shells are found within the present land area (Boulton 1979; Forman \& Miller 1984). The high relative sea level indicated by the $87 \mathrm{~m}$ terrace requires the existence of a major Barents Sea ice sheet at the time of its formation, whether that occurred around 36,000 years B.P. or earlier.

\section{References}

Andersen, B. G. 1981: Late Weichselian ice-sheets in Eurasia and Greenland. Pp. 1-65 in Denton. G. H. \& Hughes, T. H. (eds.): The last great ice sheets. John Wiley \& Sons, New York.

Boulton, G. S. 1979: Glacial history of the Spitsbergen archipelago and the problem of a Barents Shelf ice sheet. Boreas $8,31-57$.

Boulton, G. S., Baldwin, C. T., Peacock, J. D., McCabe, A. M., Miller, G., Jarvis, J., Horsefield, B., Worseley, P., Eyles, N., Chroston, P. N., Day, T. E., Gibbard, P., Hare, P. E. \& von Brunn, V. 1982: A glacio-isostatic facies model and amino acid stratigraphy for late Quaternary events in Spitsbergen and the Arctic. Nature 298, 437-441.

Denton, G. H. \& Hughes, T. J. 1983: Milankovitch theory of ice ages: Hypothesis of ice-sheet linkage between regional insolation and global climate. Quaternary Research 20, 125 144.

Denton, G. H., Hughes, T. J. \& Karlén, W. 1986: Global ice- 


\section{$278 J$. Mangerud et al.}

sheet system interlocked by sea level. Quaternary Research $26,125-144$.

Elverhøi, A. \& Solheim, A. 1983: The Barents Sea ice sheet a sedimentological discussion. Polar Research I n.s., 23-42.

Elverhøi, A., Lønne, $\emptyset$. \& Seland, R. 1983: Glaciomarine sedimentation in a modern fjord environment. Spitsbergen. Polar Research I n.s., 127-149.

Forman, S. L. \& Miller, G. H. 1984: Time dependent soil morphologies and pedogenic processes on raised beaches. Brøggerhalvøya, Svalbard archipelago. Arctic and Alpine Research 16, 381-394

Landvik, J. Y., Mangerud, J. \& Salvigsen, O. 1987: The Late Weichselian and Holocene shoreline displacement on the west-central coast of Svalbard. Polar Research 5 n.s., $29-44$.

Mangerud, J.. Elgersma, A. Helliksen, D., Landvik, J. \& Salvigsen, O. 1984: The Late Weichselian (25-10 ka B.P.) glacial maximum in Isfjorden and Van Mijenfjorden, Spitsbergen, Svalbard. Abstracts 13th Annual Arctic Workshop. INSTAAR, University of Colorado, Boulder, 67-68.

Mangerud, J. \& Salvigsen, O. 1984: The Kapp Ekholm section, Billefjorden, Spitsbergen: a discussion. Boreas 13, 155-158.
Miller, G. H. 1982: Quaternary depositional episodes, western Spitsbergen, Norway: aminostratigraphy and glacial history. Arctic and Alpine Research 14, 321-340.

Ohta, Y. 1982: Morpho-tectonic studies around Svalbard and the northernmost Atlantic. Pp. 415-429 in Embry, A. F. \& Balkwill, H. R. (eds.): Arctic geology and geophysics. Canadian Society of Petroleum Geologists Memoir 8.

Salvigsen, O. 1981: Radiocarbon dated raised beaches in Kong Karls Land. Svalbard, and their consequences for the glacial history of the Barents Sea. Geografiska Annaler 63A, 280291.

Svendsen, J. I., Landvik, J. Y., Mangerud, J. \& Miller, G. H. 1987: Postglacial marine and lacustrine sediments in the lake Linnévatnet, Svalbard. Polar Research 5 n.s. (this volume).

Troitsky, L., Punning, J-M., Hütt, G. \& Rajamäe, R. 1979: Pleistocene glaciation chronology of Spitsbergen. Boreas 8, 401-407.

Vorren, T. O. \& Kristoffersen, Y. 1986: Late Quaternary glaciation in the south-western Barents Sea. Boreas 15, 5160 . 